\title{
SLAYING THE HYDRA: LIVING TREE CONSTITUTIONALISM AND THE CASE FOR JUDICIAL REVIEW OF LEGISLATION
}

\author{
Tom CAMPBELL
}

Resumen:

En su libro A Common Law Theory of Judicial Review: The Living Tree, Wil Waluchow de manera elegante y sutil evita la crítica al judicial review con el argumento de que los derechos constitucionales son irremediablemente indeterminados y sostiene que precisamente por este aspecto de indeterminación un método basado en el common law es adecuado para la interpretación de los derechos. Sin embargo, su postura de que los jueces son capaces de "descubrir" las perspectivas morales "auténticas" de los ciudadanos no está bien fundamentada como para hacer frente a la crítica de que el método del common law, al utilizar dicho material poco específico, da como resultado decisiones controvertidas que reflejan los valores y experiencia de una elite profesional y social no representativa. También el argumento de Waluchow ignora que la democracia electoral tiene como objetivo proteger a mayorías vulnerables de poderosas minorías. No obstante lo anterior, la tesis de Waluchow puede ser más viable donde exista la posibilidad práctica de una revisión efectiva de las leyes a través de las decisiones propias del método del common law en el ámbito de los derechos humanos.

Palabras clave:

Common law, teoría del judicial review, constitucionalismo, interpretación jurídica, derechos humanos, Wil Waluchow. 


\section{TOM CAMPBELL}

\section{Abstract:}

In A Common Law Theory of Judicial Review: The Living Tree, Wil Waluchow neatly sidesteps the critique of judicial review based on the contention that constitutional rights are unacceptably indeterminate by arguing that it is this very indeterminacy that makes a common law method of legal interpretation appropriate. However, his contention that judges are able to 'discover' the underlying 'authentic' moral views of citizens is insufficiently grounded to meet the objection that common law reasoning utilising such unspecific material will result in controversial decisions that reflect the values and experience of an unrepresentative social and professional elite. He also ignores the important fact that electoral democracy is partly about the protection of vulnerable majorities against powerful minorities. However, Waluchow's approach could be rendered more acceptable where there is the practical possibility of effective legislative review of common law style decision-making in the arena of human rights.

Keywords:

Common Law, Judicial Review Theory, Constitutionalism, Legal Interpretation, Human Rights, Wil Waluchow. 
Summary: I. Introduction. II. The Monster. III. Changing the Context. IV.Conclusion.

\section{INTRODUCTION}

Myth or monster, there would appear to be no fatal blows that can be dealt to the case for substantive judicial review of legislation. The idea that enhancing judicial power over an ever wider range of political matters is progressive, and even democratic, is now so firmly favoured by the majority of scholars with an interest in constitutionalism, that cogent attacks on arguments presented under one head for adopting court-administered Charters or Bills of Rights, result, not in mortal wounds, but in a multiplicity of new heads of argument, often with quite contrary rationales, for promoting some form of juristocracy.

No sooner has the Herculean Jeremy Waldron demonstrated the implausibility of the assumption that the specific content of Bills of Rights, as statements of fundamental rights, can be agreed upon by the vast majority of rational persons, ${ }^{1}$ thus undermining the basis of the central case for taking final decisions about such rights out of parliaments and into courts, than we are confronted with the thesis that, Bills of Rights aside, the fundamental principles of the common law can suffice for courts to keep democratic governments in check. ${ }^{2}$ Following a similar pattern, powerful historical critiques of this type of "common law constitutionalism' 3 is put to one side and replaced by ahistorical versions of the common law approach, asserting the alleged intrinsic superiority of judge-made law generally over its more democratic alternatives.

1 Waldron, J., Democracy and Disagreement, Oxford University Press, 1999.

2 Allan, T. R. S., Constitutional Justice: A Liberal Theory of the Rule of Law, Oxford University Press, 2001, pp 201-242.

3 Goldsworthy, J., The Sovereignty of Parliament: History and Philosophy, Oxford University Press, 1999; Tubbs, J. W., The Common Law Mind: Medieval and Early Modern Conceptions, John Hopkins University Press, 2000. 
Now, rising above the apparently mortal blows to judicial review of legislation dealt by both Waldron and Goldsworthy, Wil Waluchow argues that it is precisely because statements of fundamental rights are indeed indeterminate and morally controversial that their substance should be worked out through legally, not democratically based process. ${ }^{4}$ The Hydra of substantive judicial review rationalisation not only survives, but flourishes, despite the telling critiques of its intellectual and historical foundations.

This caricatured and over-dramatised introduction to Wil Waluchow's Canadian-focussed case against 'Charter Critics' and in favour of a 'living tree' approach to constitutional interpretation is not intended to belittle the importance of his recent book In fact, this disarming, scholarly and original work deserves, and has already received, serious critical attention. Further, its theme is in tune with the way in which bills of rights are currently being used: less to protect fundamental civil liberties, such as freedom of expression, and more to promote progressive social causes, such as same sex marriage.

Waluchow seeks to counter the Charter Critics' onslaught on the thesis that Charters offer a guarantee that courts can and will protect certain fundamental rights against the evils and inattentions of 'majoritarian' democracy. He turns the tables on those who point out that the content of court-based decisions about fundamental rights are inherently contentious by arguing that this is precisely why the specific meanings to be officially attributed to rights should be a gradually evolving matter that involves the impartial reasoning skills of judges whose institutional independence and constant exposure to the moral claims of individuals against the state renders them better fitted for the task than representative governments. He carries through this rather optimistic perspective on legal process with a philosophical sophistication that goes beyond the standard

4 Waluchow, W. J., A Common Law Theory of Judicial Review: The Living Tree, Cambridge University Press, 2007. 
critiques of the poor quality of political debate and the dismal rationality of public opinion that are the usual scene setters for affirming the relative supremacy of judicial over parliamentary reasoning.

Waluchow does not, however, propose the sort of common law constitutionalism which says that we can, and perhaps should, do without Charters and Bills of Rights and simply require judges to protect the fundamental rights enshrined in the common law tradition, albeit suitably developed and applied to contemporary circumstances by the deployment of common law adjudicative methods. ${ }^{5} \mathrm{He}$ acknowledges that Charters go beyond established common law and provide authoritative texts, which themselves may have some democratic legitimacy, that should be interpreted utilising common law methodologies. He, therefore, avoids the more extravagant, not to say fictitious, claims made on behalf of the moral authority of common law as a historical phenomenon.

Nor does Waluchow make the mistake of seeking to base judicial review on inflationary conceptual analyses of such ideals, such as 'legality' and 'the rule of law', as a way of establishing that certain moral matters are incontrovertibly within the provenance of courts rather than parliaments or elected governments. ${ }^{6}$ The philosophical arguments he deploys come from substantive philosophical sources, such as discourse theory, Rawls and Dworkin, rather than conceptual sleight of hand involved in pre-packaging 'the concept of legality' with substantive values and then concluding that law-making on the basis of these values is, by definition, a judicial function, for it is courts, after all, that have a primary concern for legality and the rule of law.

Another strength of the book is that it does not trade on the fallacy that because courts have in certain historical periods 'recognised' parliamentary sovereignty, this means

5 Laws, J., "The Constitution: Morality and Rights”, Public Law, 1996, 662.

6 Dyzenhaus, D., The Constitution of Legality, Cambridge University Press, 2006. 
that parliamentary sovereignty is morally and legally based on the 'authorisation' thereby given to it, and is therefore able to be taken away or modified, by judicial determination. ${ }^{7}$ The historically naive contention that judicial authority is 'logically' prior to the political authority derived from the political adoption of democracy as a system of government is a stock in trade of some of the more extravagant versions of the so-called common law constitutionalism. Mercifully, it does not feature in Waluchow's book.

A Common Law Theory of Judicial Review is, therefore, a refreshingly novel head of the judicial review Hydra, and one that deserves our careful consideration. The points that I make by way of critical comment, and then for the purpose of creative adaptation, seek only to wound and then to heal, not to slay.

\section{The Monster}

The central critical points to be brought to bear on Waluchow's common law theory of judicial review relate to its potentially extreme consequences for the authority of elected governments. The apparently benign suggestion that courts should gradually and carefully, on a case by case basis, give applicable content to the rights which they use to invalidate or radically reinterpret legislation, amounts, cumulatively to an extraordinarily open-ended power that can be effectively limited neither by Charter amendment nor parliamentary override. ${ }^{8}$

This critique may seem alarmist in the light of the first strategic move in the development of the case for 'living tree' interpretations of constitutional rights, which is to abandon a central claim of Charter enthusiasts, that such

7 Allan, op. cit., p. 271.

8 A point well made by Grant Huscroft, who notes that living tree interpretation 'offers the most extensive conception of judicial review'. See Huscroft, G., "The Trouble with Living Tree Interpretation", University of Queensland Law Journal, vol. 25, 2006, pp. 3-23. Compare Kavenagh, A., "The Idea of a Living Constitution", Canadian Journal of Law and Jurisprudence, vol. 16, 2006, pp. 3-23. 
constitutional devices provide some sort of guarantee concerning the protection of an agreed set of fundamental rights. In his words: 'The simple fact is that a Charter cannot do what its most vociferous advocates often maintain. It cannot, for example, possibly live up to the ideal of letting citizens know what their rights are, or of representing a society's guarantees to it members - particularly its minority members - that certain enunciated rights will be observed and respected in subsequent decisions made by that society's lawmakers. The Critics are correct: One cannot commit to $\mathrm{X}$ if one does not even know what $\mathrm{X}$ is. One cannot possibly guarantee that "citizens know exactly what their rights and freedoms are... 'if we disagree radically about what these rights and freedoms actually are.' 9

Dropping the goal of providing judicial guarantees of fundamental rights protection through pre-commitment to such rights is a huge concession to the case made by Waldron and others against Charters and in favour of Parliaments. Analysing the arguments presented, for instance currently in Australia, for the adoption of some form of Bill or Charter of Rights, shows these consist overwhelmingly of arguments which start by accepting that the protection of human rights is by and large alive and well in Australia, but go on to assert that, these rights could, at any time, be taken away because of 'Australian exceptionalism' amongst democracies in not having a Bill of Rights. To guarantee our basic rights against unforseen developments, we must, it is argued, have court-administered Bills of Rights. ${ }^{10}$ This echoes the case made in New Zealand before the enactment of its Bill of Rights Act $1990^{11}$ and the UK before the enactment of its Human Rights Act 1998. Omit that argument, and the pro-Charter case as currently presented in Austra-

9 Op. cit., note 4, p. 10.

10 Charlesworth, H., Writing in Rights: Australian and the Protection of Human Rights, Sydney, UNSW Press, 2004; Williams, G., The Case for An Australian Bill of Rights, Sydney, UNSW Press.

11 White Paper, A Bill of Rights for New Zealand. 
lia, and maintained in the face of contrary experience elsewhere, is radically weakened. Yet, this is precisely what living tree constitutionalism does since it accepts as a major premise that it is difficult if not impossible to know in advance what precisely the rights are that the courts will protect against legislative malfeasance.

Moreover, not only does abandoning the pre-commitment approach to fundamental rights remove the principal reason historically given substantive judicial review, it also removes the formal constraints of the text of a Charter of Rights on the use of judicial discretion in the exercise of judicial review through the application of what are, in the theory, seen as indeterminate statements of ill-defined values. This point is aptly made by Larry Alexander when he asks whether, under the living tree approach directed to the application of existing constitutional values, the words of the original Charter have any force or relevance whatsoever. 12

However, while one advantage of the 'guarantor' approach to Bills of Rights is that it purports to limit the use of such Bills to extreme cases of clear rights violations, an advantage that would appear to be lost when Waluchow accepts the indeterminacy of Charter provision and builds on this basis to commend the living tree approach, Waluchow's concession to Waldron is not as complete as it at first appears. His book starts out acknowledging Waldron's insistence on the extent of disagreement over the content and scope of human rights, and thus over the 'interpretation' (the standard euphemism) or 'specification' (my preferred term) of these rights as they are applied in court, but he goes on to argues for a considerable degree of 'deep' agreement as to fundamental values and their paradigm applications, not in the original meaning of Charter rights, but in the 'constitutional morality' of the community. In places, he effectively denies deep value pluralism and seeks to explain away surface disagreement as a consequence of uninformed

12 L. Alexander, this volume. 
and inauthentic opinion, and manifesting false, rather than 'true moral commitments'. ${ }^{13}$ Contrary to Waldron ${ }^{14}$, Waluchow contends that fundamental value disagreement in countries 'such as the United States, Canada, Germany and Mexico' are neither profound nor intractable, for judges are able to see beneath the surface pluralism to the authentic views of the people which are not undermined by the sort of deep radical disagreement to which Waldron draws attention.

The idea that there is an underlying implicit value consensus is fundamental to the logic of the book. It enables Waluchow to deny that activist judges updating and tailoring abstract rights to the specific cases of the time must draw on their own moral views and override the wishes of the communities in which they operate. Rather, Waluchow argues, judges are able to discern the real rather than the actual wishes or 'opinions' of communities. Making a distinction that is reminiscent of Rousseau's controversial contrast between the 'general will' and the 'will of all', a conceptualisation that has been used to justify powerful minorities taking charge of the state and imposing their views on the majority while claiming that they are only carrying out the real wishes of the people, Waluchow contrasts the authentic moral views of communities of citizens who have carefully and accurately reflected on the implications of their basic values, on the one hand, with the ordinary and unreflective opinions that they actually bring to bear

13 Waluchow, op. cit., note 4, p. 226. Italics in the original. $C f$. p. 222: 'I suggest that on many questions of political morality that arise in Charter challenges there is some measure of overlapping consensus within the relevant community on norms and/or judgments concerning justice, equality and liberty that would emerge from careful reflection... A society that differs in many of its surface moral opinions is often one in which there is considerably more agreement than initially meets the eye - even if these agreement are "incompletely theorized" and even if they emerge only after an attempt has been made to eliminate signs of evaluative dissonance". Waluchow appears to accept that what Waldron takes as only apparent agreement on general principles is in fact genuine agreement.

14 Waldron, J., "Some Models of Dialogue Between Judges and Legislators", in Huscroft, G. and Brodie, I. (eds.), Butterworths, 2004, pp. 7-48 at 11-12. 
when debating and voting in the real world of democracy, on the other hand.

Waluchow starts with the sound observation that we are not always aware of the full implications of the views we hold and goes on to make the bold claim that courts are better than parliaments at discerning what these unacknowledged implications are. This takes him to the conclusion that it is legitimate for courts to interpret the "moral rights' contained in Charters in accordance with their discernment of the 'authentic' rather than expressed constitutional morality of the time. This part of the argument is crucial, not only in the general justification of the dominant role of courts in interpreting Charters and d reviewing legislation, but also in establishing that courts are effectively limited in the interpretations they make by the fact that the proper exercise of this power is to discover authentic constitutional moral views of the community rather than engage in independent moral reasoning based on the moral values held by the judges themselves.

However, not only is there no way of ensuring that the judges exercising these powers accept this view of their constitutional methodology, but, even if they do seek to follow Waluchow's model, there is no way of knowing if they are successful in discovering what this constitutional morality consists of. 15 The application of principles and highly abstract rules to different aspects of social life raises moral not just factual disagreements about the possible interpretation and application of those principles and their comparative weight in relation to other relevant moral considerations. A belief in political equality, for instance, does not extrapolate mechanically to a belief in economic equality. Waluchow acknowledges that this is a complex and difficult process of reflection and choice, and spends some time in exploring the application of the Rawlsian devices of reflec-

15 Sometimes Waluchow claims no more than that it is possible for courts to adopt his method of common law constitutionalism. See op. cit., note 4, p. 229. In other places he makes the stronger claim that they actually do so, e.g: p. 236, and p. 238. 
tive equilibrium and overlapping consensus ${ }^{16}$ as ways of overcoming these problems. Ultimately, however, he can provide no hard evidence, that such methods applied in legal contexts are able to bring to the surface agreement as to the content of an underlying consensus built on 'authentic' value beliefs. There remains the strong suspicion, therefore, that the task Waluchow sets for common law reasoning with respect to working out the true implications of shared common values (i) wrongly claims, at the level of theory, to be a matter of discovery rather than creation ${ }^{17}$ (ii) is in practice liable to result in a projection of the values and experience of a small and unrepresentative social and professional elite.

Waluchows's thesis that courts are good surrogates for, or exemplars of, deliberative democracy is questionable, with respect to the quality of reasoning found in law reports, the procedures actually followed in reaching judicial decisions, and the competencies attributed to courts. The factors which Waluchow himself draws on to justify his preference for legal reasoning over democratic debate, when it comes to constitutional morality, cannot bear the weight that he places on them. Thus, he attributes great significance on the fact that judges have economic independence and job security. Yet 'independence', as the absence of a personal benefits or harms resulting from the decision to be made is not sufficient to attribute the sort of impartiality that is sufficient to bring about fair balances between competing values and interests; something which depends on the extent to which those involved share the values and interests of the contending parties. Here Waluchow optimistically contends that 'despite their [the judges'] vested interests, it is nevertheless reasonable to hope and expect that they will be able, in deciding contentious moral issues, to

16 Op. cit., note 4, p. 222.

17 Waluchow, p. 228: 'I have done little beyond establishing the live possibility that, the Critics skepticism, notwithstanding, an overlapping consensus of true commitments might indeed be there to be discovered. 
bracket those interests when they make their decision that is they will be able to display the same judicial virtues of objectivity, impartiality, and neutrality that they are generally thought to display in deciding other types of cases'. ${ }^{18}$

Waluchow puts even more weight on the point that legislation deals with generalities while judicial decision-making relates to particular cases. Inevitably, he points out, legislators cannot anticipate all the situations that might arise and courts are therefore skilled in taking into account the particular factors that arise in the real world of specific instances: 'Recall that legislatures cannot, for reasons of sheer practicality, enact legislation specific to each and every individual case that might arise in a particular social context. They must, of necessity, work with general categories covering a range of somewhat different individual cases'19 and judges 'are in a better position to appreciate the particular issues raised in the cases in which these impacts are felt and who will be able, through their use of common law methodology, to deal with those issues in an intelligent, sensitive case-by-case method'. ${ }^{20}$

This is a familiar and pertinent point to make in favour of enabling courts to modify statutory rules to accommodate gaps and anomalies in existing positive law, and raises no major problems for democratic theory where legislatures are able either to acquiesce in the developing case law, or to amend the legislation in question, if they so choose. Courts evidently have something to contribute to legal development through the particularity of their focus and their exposure to individualised real life disputes, but courts are not in position to give equal consideration to all interests affected by law-making as opposed to the interests of contending parties and their ilk. Inevitably a case-based approach gives priority attention to the interests of the parties to the case in question rather than other individuals or groups within

18 Op. cit., note 4, pp. 235-6.

19 Op. cit., note 4, p. 234.

20 Op. cit., note 4, p. 235. 
society as a whole, and do so in a sphere where wealth and technical expertise tends to dominate.;

The situation is very different however, if the common law decisions are constitutional ones that are not subject to legislative review and are not readily altered by constitutional amendment. Moreover, Waluchow does not give sufficient weight to countervailing factors. Courts are, or should be, constrained by the need to articulate issues and arguments in terms of existing legal statutes and precedents; something which does not apply to democratic discourse which is more open to new demands and arguments. Further, courts do not have policy making competence with respect to information, social science expertise and political efficacy. In these respects courts can be no substitute for governments. Again, these are familiar points, but Waluchow passes over them without acknowledging that such advantages as may arise from using common law methodology in ordinary law do not translate neatly into the sphere of constitutional interpretation. Indeed, despite the attractiveness of common law methodology as gradualist and incremental, he ignores the fact that common law decisions are cumulative and can lead to radical, and, in constitutional contexts, in practice often irreversible changes.

Within this analysis there is a certain obscurity in Waluchow's treatment of the force and direction of common law decision-making in constitutional domains which derives from his variable slants as to the nature and role of 'the common law'. In its constitutional application Waluchow gives to common law reasoning a particular function, identifying the real or genuine community values that constitute its constitutional morality. This quasi-Dworkinian objective does not seem to derive from common law in the sense of long-established customary law or common law as the repository of judicial wisdom, but from the particular situation and reasoning skills of current judicial officers seeking to adapt constitutional provisions to changing social circumstances, including the developing moral beliefs 
of the community and the implications of the correct understanding of these evolving moral beliefs. There must be some concern at the transfer of the (possible) achievements of the common law historically, as represented in the principles that are justified because they have evolved and tested over a long period of time (a legal myth to which Waluchow himself gives no particular credence and for which there is mixed historical evidence and on which there is little normative agreement) to the commended application of common law methodology to constitutional interpretation of (in most cases) relatively new legal texts. This is particularly the case where there is a global culling of precedents from a multiplicity of jurisdictions that enables courts to pick and choose as they please. While the common law of the last 200 years has been shaped by the external pressures deriving from public opinion, democratic politics, statutory intervention and the conceded legitimacy of legislative review of common law rules and principles, the projected common law theory of judicial review is, by design, sheltered from at least some of these pressures, thus making it improper to infer that the benefits of common law within a system or Parliamentary sovereignty can be extrapolated to a situation where that democratic corrective function does not operate, when, on constitutional matters, courts have the last word.

Waluchow sometimes seeks to evade these points by denying that he is seeking to justify 'strong' judicial review where the decisions of courts are decisive in the invalidation or non-application of statutory law, as in the United States, but not, he contends, in New Zealand, or in the UK and certainly not, in Canada. This neglects to consider evidence that the apparently weaker forms of judicial review in these countries are set up and administered in such a way that they result in de facto overriding judicial power that is far removed from the rather cosy conception of a 'dialogue' between courts and parliaments favoured by some commentators on constitutional practice in these jurisdictions. 
This debate tends to lose sight of the fact that democratic systems are not only arenas for debating the public good, but are also mechanisms whereby those who are governed can protect their interests and implement their ideas of public justice against those whom they perceive as hostile and unjust in their exercise of political power. Democracy is, in large part, about the protection of vulnerable majorities against powerful minorities. The democratic ideal of the equal distribution of political power can be seen as a matter both of enhancing the intrinsic dignity of the individual and as a means of controlling and utilising the self-interested conduct of rulers. The case for judicial review focuses on the fact that actual democracies fails to distribute that power equally in practice, thus giving rise to the problem of vulnerable minorities. It may therefore be portrayed judicialising constitutional power as an improvement on 'majoritarian' democracy. However, the attempt to improve majoritarian democracy by protecting relatively powerless minorities can do so only at the expense of limiting the larger benefits of democracy nby reducing the power of actual and potential majorities to protect their interests and further their views against otherwise unaccountable governments. This is of immense significance if it is held that in any large scale society majorities are highly vulnerable to the oppressive controls of powerful minorities. This dimension of the democratic function is insufficiently recognition within the dialogue model of strong judicial review.

In the end, it is not clear that these complex social processes are illuminated by the 'living tree' analogy and its accompanying string of obiter dicta drawn from constitutional law cases. ${ }^{21}$ The living tree analogy is an apparently benign and pleasing figure of speech that feeds off a pre-modern conception of naturalism and natural law but, in itself, offers no reason why we should adopt such a world view. Systems of law are not natural organisms like plants with pre-ordained norms of health, growth and purpose.

21 Edwards $v$. The Attorney-General of Canada [1930] AC 123. 
Even if they were, this does not determine who is best suited to select the plants, be the gardener or prune the tree. The simile has little, if any, independent purchase and, indeed, reflects background assumptions that run counter to Waluchow's living tree constitutionalism, As applied to the common law specifically, it suggests the idea of common law as long established custom rooted in a particular culture, rather than a process of political deliberation on contemporary values and their practical applications. With respect to common law as judge made law, it identifies no natural limits to the scope of the common law, such as applies to the cultivation of trees. It fails to capture the powerful internal role of human agency within the common law, or point up the trial and error aspect of precedential development. Politically, the living tree simile begs the question as to the relative virtues of constitutional fixity and plasticity, and ignores the availability of procedures for radical constitutional amendment.

\section{Changing the Context}

The plausibility of Waluchow's model of constitutional reasoning changes with the context and issues to which it is applied. Thus, the living tree approach does make us face the problem of how entrenched constitutions are to be developed in contexts where extra-legal forms of constitutional change are not readily available. Most discussions of this issue make the false assumption that constitutions must be, by definition or incontrovertible conceptual analysis, entrenched. This ignores the possibility that the best solution to the need for constitutional updating is to make them subject to the normal legislative processes of amendment change. That aside, it is remarkable how little attention is given in contemporary legal philosophy to facilitating the procedures for amending entrenched constitutions, including making amendment more acceptable and less arduous. Yet, it is evident that entrenched constitution-makers 
did not intend judges to do the updating for which they laid down strict and relatively clear procedures for amendment. The ready acquiescence in judicial activism, whether or not within some common law methodology, as the preferred mode of constitutional change, ignores the available alternatives. In constitutional contexts where constitutional change, either by statute, referendum or more elaborate mechanisms, is a common and accepted phenomenon, some of the democratic deficits of Waluchow's model do not apply.

Further, the common law theory of judicial review can be made much more palatable where there is a democratic system which assumes the propriety of legislative review of common law decisions and, therefore, of Waluchow's version of common law constitutionalism. Thus, if the "notwithstanding' clause of the Canadian Charter were politically operative and its routine use more ideologically acceptable, then there is something to be said for allowing a measure of leeway in judicial interpretation of a Charter on the basis of the epistemological benefits that flow from their exposure to particular cases and detachment from certain political pressures. A judicial brief to be on the look-out for selfish majoritarianism, the vested interests of politicians, and dilutions of democratic rights, has its attractions provided the courts do not have the final say in such controversial matters. When the case for strong judicial review is made to rest on the pre-Waldron view that there are clear fundamental rights whose applications call for legal not political judgment, this makes it seem improper for Parliaments to have ultimate custody of their specification. However, on the Waluchow approach, where no such certainties to be had, and the function of judicial review is to warn the public through the application of constitutional principle to legislation that governments are threatening its constitutional values, strong legislative review of judicial law-making is more legitimate, as he allows. 
Following through this line of thought, arguably, strong legislative review could be made even more acceptable if what we are dealing with is, not Charters that affirm abstract moral values, such as life, liberty and respect, to be given substance by courts, but Charters that are used by legislatures to develop detailed legislation designed to promote human rights in a concrete form. ${ }^{22}$ If we view Charters and Bills of Rights as part of a political constitution which calls for human rights legislation that is clear and specific enough to be applied by courts without engaging in controversial moral debate, then the idea of a common law approach to judicial review can be viewed along much the same lines as statutory interpretation in common law jurisdictions. Thus human rights legislation, like all legislation, could be interpreted with the assumption that legislation is not to be taken to limit established common law principles unless this is stated clearly and unequivocally. Moreover, ordinary legislation could be interpreted as similarly subordinate to human rights legislation in that human rights legislation takes precedence unless the contrary is clearly and explicitly affirmed in the legislation in question.

Within such a system, 'common law' may be viewed as a process of making the laws of a jurisdiction clear and consistent through judicial interpretation. Such 'common law positivism' can be seen as a way of making a system of positive law more consistent and specific through appellate judicial process. Its purpose is to build up a clear and coherent working body of legal rules through precedential reasoning under the guidance of established legal principles, with openness to only gradual change and giving due deference to statutory correction. Emphasising this positivist ideal as the objective of common law method and concentrating less on the, in many jurisdictions, relatively recent revival of adventurous common law decision-making 
by higher courts, presents the prospect of commending a method of constitutional interpretation that is suited to the role of courts in a democratic system.

Indeed, Waluchow's common law constitutionalism could be utilised to draw attention to the desirable of having continuity of constitutional method and legal method generally. This raises the possibility of turning on its head the common mantra that, when dealing with human rights, courts must be much more liberal and expansive in their interpretations, and commending the reverse, namely that a more traditional common law method should be applied, particularly with respect to human rights, on the grounds that human rights specification should not be located within the discretionary powers of judges untrammelled by the legislative review that is part and parcel of the right to self-government. In such a context, we could benefit from most of the advantages offered by Waluchow's common law constitutionalism with its focus on individual cases, without going along with his somewhat fanciful idea that courts have the will and the capacity to discover the possible content of a community's 'authentic' constitutional morality.

\section{CONCLUSION}

If courts did have the capacities and motivations ascribed to them by Waluchow then there would be some good reason to hand over to judiciaries all law-making powers since they would do a better job of giving the people what they really want than can be expected of elected representatives and the governments they form. This is the highly paternalistic drift of a well-meaning theory that, in the end, would, if correct, remove extensive areas of political debate from the democratic process. Regrettably, Waluchow's apparently mild approach to the political capacity of judiciaries is liable to encourage, not the institutionalised humility he 
commends, but, an enhanced institutionalised conceit. ${ }^{23}$ Living tree constitutionalism may seem, in the short term, to promise human rights benefits, but, like other approaches to the vindication of substantive judicial review, it is flawed through its implicit rejection of the belief that the equal moral standing of all human beings should be reflected in the equal distribution of political power. For all its merits, A Common Law Theory of Judicial Review: the Living Tree, must be seen as part of a growing literature that incites democracies to relinquish their birth-rights and encourages judges to act treasonably against the political constitution of democracy. To end by returning to a measure of hyperbolic drama: common law constitutionalism in its various forms is not just an academic myth concerning the advantages of creative common law methodology, it is a potential political monster which contributes to the further weakening of an already flawed democratic culture.

23 For they 'know better' than (op. cit., note 4, p. 219) and are 'superior' to others (op. cit., note 4, p. 269). 